\author{
BULETINUL INSTITUTULUI POLITEHNIC DIN IAŞI \\ Publicat de \\ Universitatea Tehnică „Gheorghe Asachi” din Iaşi \\ Volumul 67 (71), Numărul 3, 2021 \\ Secţia \\ CONSTRUCTII DE MAȘINI \\ DOI: $10.2478 /$ bipcm-2021-0017

\section{sciendo}

\title{
INFLUENCE OF NOZZLE PARAMETERS IN 3D PRINTING UNDER THE MANUFACTURING TIME
}

BY

\section{VASILE ERMOLAI and ALEXANDRU IONUT IRIMIA*}

"Gheorghe Asachi" Technical University of Iaşi,

Faculty of Machine Manufacturing and Industrial Management, Iaşi, Romania

Received: April 2, 2021

Accepted for publication: June 25, 2021

Abstract. Actually, the Fused Deposition Modelling is one of the most popular Additive Manufacturing technology among ordinary users because of the low-cost equipment and the great variety of materials available on the market. Even many users mostly use it, not all of them are adopting the advanced parameterisation of the processes, preferring default set-up with a small interference over the basic parameters such as layer height, number of perimeters, and infill. Regarding the nozzle diameter, several advantages and disadvantages are implied by the relation of printing time-surface finish. Usage of large-diameter nozzles present advantages such as reduced manufacturing time, low risk of clogged nozzle, and more. Those cause worse resolution for small features and support structures to be more challenging to remove. By adjusting the nozzle parameters such as extrusion width and extrusion temperature, it was possible to obtain similar effects with a regular nozzle. This research's main goal was to investigate if there is imperative the usage of largerdiameter nozzles for speeding up the manufacturing process, or the same effect can be achieved by using nozzles with a smaller diameter. In the end, we managed to reduce the manufacturing time to half compared to the initial time.

Keywords: Fused Deposition Modelling; nozzle diameter; extrusion parameters; manufacturing time; surface finish.

*Corresponding author; e-mail: irimiaionut95@gmail.com

(C) 2021 Vasile Ermolai et al.

This is an open access article licensed under the Creative Commons Attribution-NonCommercialNoDerivatives 4.0 International License (CC BY-NC-ND 4.0). 


\section{Introduction}

3D printing has become one of the most popular manufacturing technologies having a wide range of users from hobbyists to professionals. Factors such as low-cost equipment, low-cost raw material and a large community of users offering support and knowhow make Fused Filament Fabrication one of the most popular 3DPrinting technologies on the market. Besides those, the desktop size of equipment offers the opportunity to be integrated even in small spaces and plays an essential role in spreading this technology. What everyday users understand by 3DPrinting is a technology belonging to the Extrusion Additive Manufacturing - EAM family. Firstly, patented under the name of Fused Deposition Modelling - FDM. This technology was developed by S. Scott Crump at the end of the '80s and is a trademark of Stratasys (Gibson et al., 2010). The development of similar equipment with different ways for building the parts led to a rebranding on the market and names like Fused Filament Fabrication - FFF (Weiner, 2020).

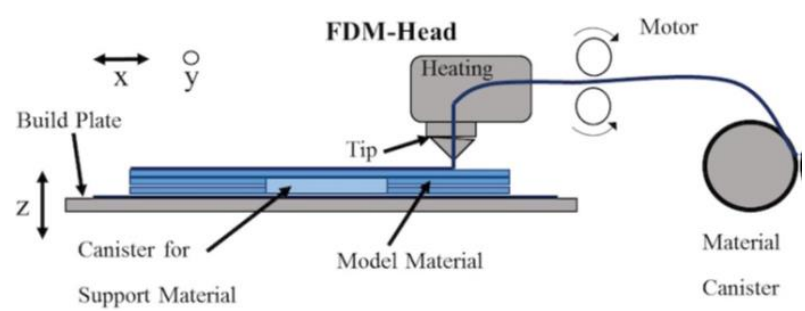

Fig. 1 - FDM 3DPrinter scheme (Baich et al., 2015).

Fused Filament Fabrication is a simple extrusion process integrated on a 3-axis CNC machine using thermoplastic as raw material (Gibson et al., 2010). The raw material is coming from spools and heated at a specific temperature given by the material properties. The filament is forced through a nozzle using a feeding system and deposited layer-by-layer in the required locations at a constant rate, which then cooled and solidified (Fig. 1). Depending on the used material, the cooling can be improved by using cooling fans integrated into the extrusion system. Multiple passes are necessary to fill the required section. When the layer is finished, the build platform moves down, or the extrusion head moves up (depending on the machine configuration), and the deposition of a new layer starts (Redwood et al., 2017). This process repeats until the model is complete. The part is removed from the build plate after the process is complete. Additional post-processing operation may be required if the desired model need support structures or specific surface finish.

Because of the increasing interest in this manufacturing technology a wide range of plastic materials are available on the market which includes the PLA (Poly Lactic Acid), ABS (Acrylonitrile Butadiene Styrene), PET/PETG 
(Polyethylene Terephthalate/Glycol), Nylon (Polyamide), TPU (Thermoplastic Poly Urethane) and others (Devicharan and Garg, 2019). Composite materials are available with different inserts such as wood, stone, carbon fibre, fibreglass and others.

Even if the material extrusion process is relatively more straightforward than other Additive Manufacturing techniques, obtaining a part that is respecting precisely, the technical documentation is not such an easy task. Many factors can influence quality the resulted part. Firstly, we need to know the purpose of the part and in which condition is exploited to set up a proper parametrisation for the manufacturing process. For example, a part that needs to sustain mechanical loads is better to manufacture the part oriented with the stressed feature in the XY plane. Furthermore, the part's strength can be improved by adjusting the raster angle and not by increasing the number of perimeters (Rajpurohit and Dave, 2019).

\section{Printing Parameters}

In this work, the only parameters that are taken into consideration are regarding the nozzle. Other parameters such as layer thickness, infill pattern or infill percentage were defined at a specific value because our primary goal is to reduce the printing time by increasing the layer width without changing the nozzle size.

Nozzles have a direct influence under the printing time and also over the part precision. Thus, with a small-sized nozzle $($ e.g. $0.25 \mathrm{~mm})$ we can obtain a more accurate part but with increased manufacturing time and with a largesized nozzle (e.g. $0.8 \mathrm{~mm})$ we can produce the same part in a shorter time but with the disadvantage that of losing parts of the details, especially for small feature sizes. The $0.4 \mathrm{~mm}$ nozzle is the most used size by most 3DPrinting users because it is a middle solution between precision and printing time (Zuza, 2018). By adjusting the extrusion width, it is possible to reduce the number of passes necessary to obtain a specified wall thickness.

The majority of slicing tools are using by default extrusion widths (Fig. 2) higher than nozzle size. For example, in the case of $0.4 \mathrm{~mm}$ nozzle, the Prusa Slicer provides an extrusion width of $0.45 \mathrm{~mm}$ (112.5\% from the nozzle tip), and the Simply3D is offering an extrusion width of $0.48 \mathrm{~mm}(120 \%$ from the nozzle size) automatically and means that it is already possible to manufacture safely (in terms of printing quality) with extrusion width larger than nozzle size. Our primary goal is to verify if it is possible to cross this range by choosing larger values for the extrusion width.

A factor influencing the optimum melting point is the colour of the plastic material or more precisely the pigments used for colourising the resin (Soares et al., 2018). Compared with other plastic material used in FFF, PLA has a high density, $1.24 \mathrm{~g} / \mathrm{cm}^{3}$, compared to ABS, which has only $1.01 \mathrm{~g} / \mathrm{cm}^{3}$. 
For this study, we used PLA black colour plastic material from Optimus Digital. The filament has a diameter of $1.75 \mathrm{~mm}$ and tolerance of $\pm 0.2 \mathrm{~mm}$. The manufacturer recommends a printing temperature sited between $190-230^{\circ} \mathrm{C}$ and the temperature for the build plate in the range of $40-60^{\circ} \mathrm{C}$.

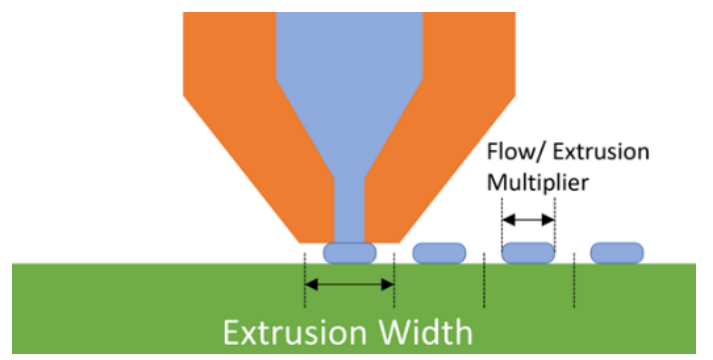

Fig. 2 - Extrusion width vs extrusion multiplier (Hermann, 2019).

In this study, Prusa Slicer the user interface used. The software helps control the position of the extrusion head to deposit the material in the required locations. Besides that, the software offers support in the visualisation of the Gcodes of each part. We set up the printing machine according to the manufacturer specifications. The equipment used for this research is a Prusa i3 Mk3s with a building volume of $250 \times 210 \times 210 \mathrm{~mm}$ (XYZ) and a precision of $10 \times 10 \times 5 \mu \mathrm{m}$ on the axes.

\section{Design of Experiment}

To study if it is possible to reduce the printing time by adjusting the extrusion width, we created a test model (Fig. 3). The model is composed of three regions: base, middle and top. The base has a rectangular shape of $20 \times 25 \mathrm{~mm}$ and a height of $5 \mathrm{~mm}$. The middle region is a frustum with each face oriented at a different angle, referring to the $\mathrm{XZ}$ and $\mathrm{YZ}$ planes. The angle values are $5^{\circ}$, $10^{\circ}, 20^{\circ}$ and $30^{\circ}$. The purpose of those is to provide information regarding the surface texture. Usually, regions with overhangs tend to result rougher, and we want to verify how the extrusion width is influencing the surface texture. The top region is a sphere with a radius of $10 \mathrm{~mm}$. Usually, the rounded surfaces have the lowest resolution when produced through the FFF because of the specific way this process is creating the parts. We expect to obtain valuable information through the usage of this feature. The gauge dimensions of this model are $20 \times 25 \times 33 \mathrm{~mm}$.

To obtain comparable results in terms of the model's wall thickness and weight, we established the value of $2 \mathrm{~mm}$ for the wall thickness as optimum. Even so, just for this value, the range of possible probes was reduced. 


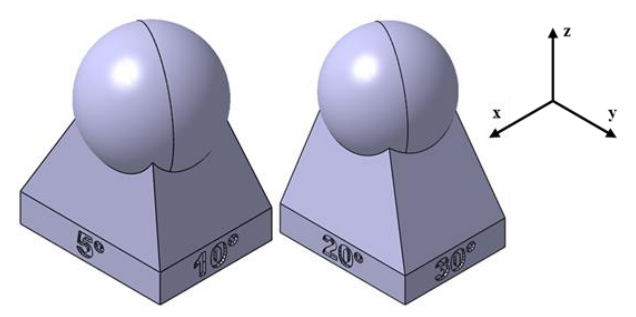

Fig. 3 -Experimental probe.

For this reason, we added tolerance to this value of $\pm 0.1 \mathrm{~mm}$. By doing so, we managed to enhance the number of comparable probes. Firstly, we calculated the extrusion width in $\mathrm{mm}$, corresponding to the range of $85-300 \%$ from five to five for the $0.4 \mathrm{~mm}$ nozzle size. Further, we established the number of perimeters necessary to fill the thickness of $2 \pm 0.1 \mathrm{~mm}$ After we selected the values that fit in the established range. We chose three values for the wall thickness 1.92, 2 and 2.08, and eight runs (Table 1). Those values are restraining the tolerance of the walls to $\pm 0.08 \mathrm{~mm}$.

Table 1

Experimental Matrix

\begin{tabular}{|c|c|c|c|c|c|c|c|}
\hline \multirow{3}{*}{$\begin{array}{l}\text { Probe } \\
\text { No. }\end{array}$} & \multirow{3}{*}{$\begin{array}{l}\text { Extrusion } \\
\text { width [\%] }\end{array}$} & \multirow{3}{*}{$\begin{array}{c}\text { Extrusion } \\
\text { width }[\mathrm{mm}]\end{array}$} & \multicolumn{4}{|c|}{ Number of perimeters } & \multirow{3}{*}{$\begin{array}{c}\text { Extrusion } \\
\text { Temperature } \\
{\left[{ }^{\circ} \mathrm{C}\right]} \\
\end{array}$} \\
\hline & & & 2 & 3 & 4 & 5 & \\
\hline & & & \multicolumn{4}{|c|}{ Resulted width [mm] } & \\
\hline 1 & 100 & 0.4 & & & & 2 & \multirow{5}{*}{200} \\
\hline 2 & 120 & 0.48 & & & 1.92 & & \\
\hline 3 & 125 & 0.5 & & & 2 & & \\
\hline 4 & 130 & 0.52 & & & 2.08 & & \\
\hline 5 & 160 & 0.64 & & 1.92 & & & \\
\hline 6 & 240 & 0.96 & 1.92 & & & & \multirow{3}{*}{205} \\
\hline 7 & 250 & 1 & 2 & & & & \\
\hline 8 & 260 & 1.04 & 2.08 & & & & \\
\hline
\end{tabular}

We used the information presented in Table 1 as input data in G-code files generations. Beside extrusion width and number of perimeters, extrusion temperature, extrusion multiplier and infill grade have been considered. We set the infill grade at $0 \%$ for two main reasons. Firstly, the infill pattern creates a supplementary perimeter inside (Fig. 4) each probe resulting with an extra width equal with extrusion width assigned to each process. For example, run no. 1 results with a value of $2.4 \mathrm{~mm}$ instead of $2 \mathrm{~mm}$ and probe no. 8 with a value of $3.12 \mathrm{~mm}$ instead of $2.08 \mathrm{~mm}$. Secondly, we want to obtain similar values regarding the weight criteria. 


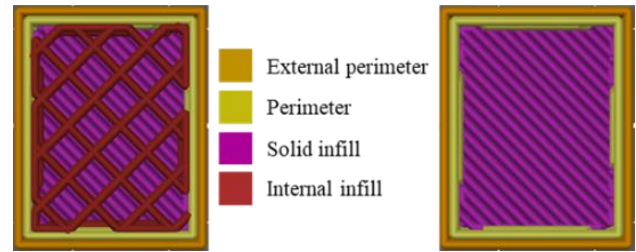

Fig. 4 - Influence of internal infill under wall thickness.

Other controlled parameters were layer height $-0.2 \mathrm{~mm}$, no. of the bottom and top layers - 4 layers each, deposition speed - $3600 \mathrm{~mm} / \mathrm{min}$ and build plate temperature $-60^{\circ} \mathrm{C}$. For other parameters, we set as default the values pre-set by the slicing tool because they were considered optimum for this research. Also, we created a supplementary G-code file for each process to facilitate the measurement procedure of the wall's thicknesses. Those instructions end at $10 \mathrm{~mm}$ from the model height to permit the measurement access with the calliper. We used the resulted values as input for Eqs. (1) and (2) to determinate the Arithmetic Mean (A.M.) of the walls thicknesses and the Standard Deviation (St. Dev.) from the imposed values. See resulted values in Table 2.

$$
\begin{gathered}
\bar{x}=\frac{1}{n} \sum_{i=1}^{n} x_{i} \\
s=\sqrt{\frac{1}{n-1} \sum_{i=1}^{n}\left(x_{i}-x_{0}\right)^{2}}
\end{gathered}
$$

Table 2

Experimental Run Results

\begin{tabular}{||c|c|c|c|c||}
\hline $\begin{array}{c}\text { Probe } \\
\text { no. }\end{array}$ & $\begin{array}{c}\text { A.M } \\
{[\mathrm{mm}]}\end{array}$ & $\begin{array}{c}\text { St. Dev. } \\
{[\mathrm{mm}]}\end{array}$ & $\begin{array}{c}\text { Printing } \\
\text { time [h: min: } \mathrm{s}]\end{array}$ & $\begin{array}{c}\text { Weigh } \\
{[\mathrm{g}]}\end{array}$ \\
\hline \hline 1 & 2.01 & 0.041 & $0: 52: 06$ & 5.07 \\
\hline 2 & 1.90 & 0.022 & $0: 45: 36$ & 4.97 \\
\hline 3 & 1.96 & 0.031 & $0: 45: 23$ & 5.03 \\
\hline 4 & 2.04 & 0.031 & $00: 45: 11$ & 5.26 \\
\hline 5 & 1.91 & 0.015 & $00: 35: 41$ & 4.96 \\
\hline 6 & 1.91 & 0.024 & $00: 24: 57$ & 4.89 \\
\hline 7 & 1.98 & 0.021 & $00: 24: 51$ & 5.06 \\
\hline 8 & 2.06 & 0.024 & $00: 24: 48$ & 5.21 \\
\hline
\end{tabular}

To ensure comparable results, we produced all models one at the time and in the same build plate region. 


\section{Printing Results}

The manufacturing process ran according to our expectations; the highest printing time results through the no.1 process because of the high number of required passes to fill the $2 \mathrm{~mm}$ thickness. By decreasing the number of perimeters, at each iteration, we managed to reduce the printing time between 7 to $10 \mathrm{~min}$ (Fig. 5). Overall, we reduced the manufacturing time with $53.67 \%$.

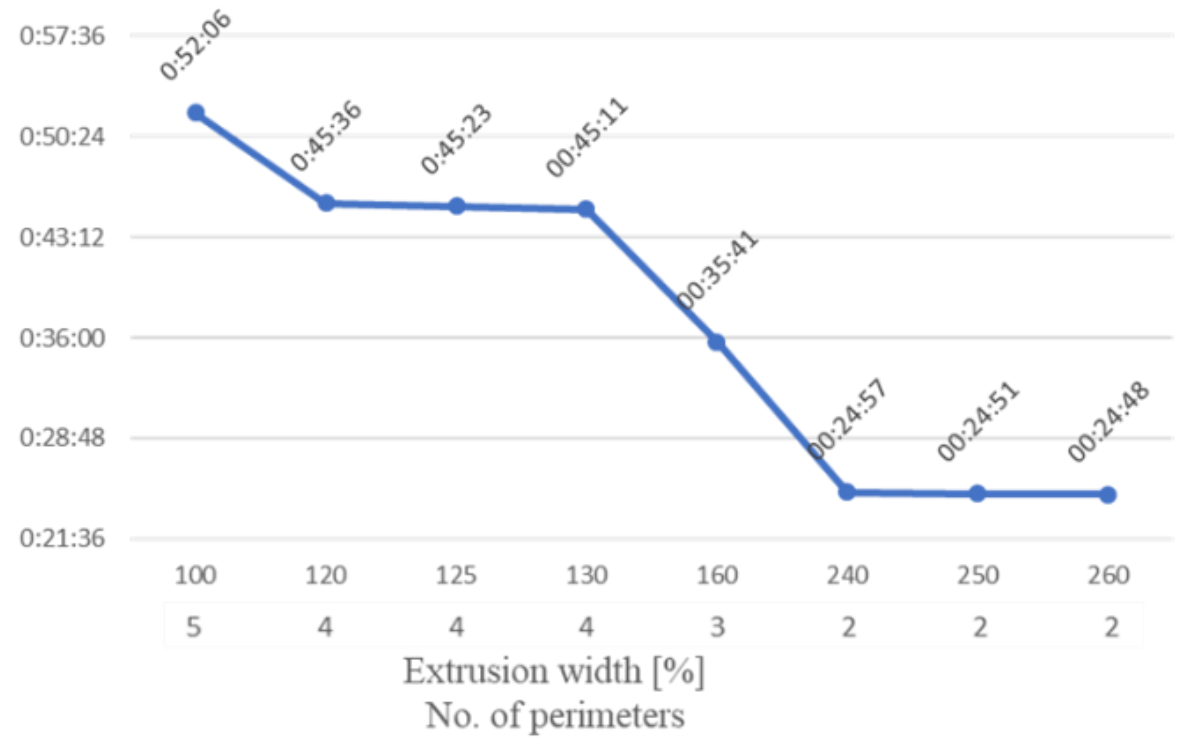

Fig. 5 - Manufacturing time reduction due to extrusion width/no. perimeters.

Three measurements were taken regarding the manufacturing precision of the thickness for each wall of the probes. We determined the arithmetic mean for each wall with the resulting values, and after we calculated the standard deviation from the nominal value. The highest value of the standard deviation was $0.050 \mathrm{~mm}$ (Table 2), which is an excellent result for the FFF manufacturing process.

Referring to the mass values, we analysed those in groups depending on the wall thickness. We observed a natural increase in the mass, starting from 1.92 to $2.08 \mathrm{~mm}$ in thickness. Between the probes of each category, we did not record any significant variations. The highest difference between the parts of each category was $0.05 \mathrm{~g}$ (Table 2 ). 


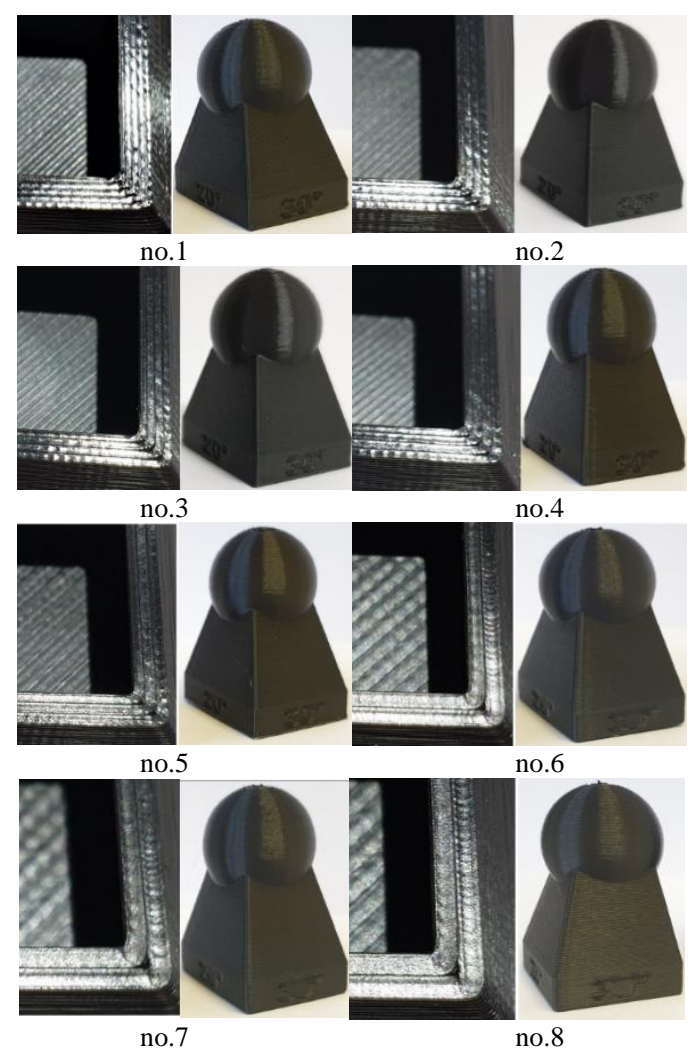

Fig. 6 - Printing results.

We observed no relevant differences for the middle and top regions of the resulted models regarding the surface texture. In the bottom areas, we remarked that as the layer width increases the resolution of the indicating marks decreases. Even if in the case of the run no. 8 with an extrusion width of $260 \%$, the inscriptions are still readable (Fig. 6), which represents a remarkable finding. Referring to the staircase effect specific to the FFF process, we did not observe notable differences between the probes. Even at high extrusion widths (i.e. $0.96,1.00$ and $1.04 \mathrm{~mm}$ ), the walls' dimensional accuracy remains at proper values. The highest deviation from the nominal value did not exceed 50 microns through all the runs, which is a very satisfying amount.

\section{Conclusions}

With the increasing interest in the Additive Manufacturing technologies, manufactures have improved their equipment year by year, making them faster and more accurate. Even so, in terms of manufacturing time 
reduction, advanced parametrisation can be a powerful asset. As we proved in this research, it is possible to obtain results comparable with nozzles that are up to 2.5 times bigger. This finding showed that it is not imperatively necessary to use a larger nozzle to decrease the manufacturing time. Similar results can result by using a small or regular size nozzle. This affirmation is strengthened by the walls' measurement results, which showed slight variations from the walls' nominal values. The proper adjustment of the extrusion width parameter led to reduced printing time. By increasing the extrusion width, the required number of passes to fill the desire thickness decrease. Thus, we managed to obtain a printing time reduction of more than $50 \%$ without changing the nozzle size. This finding can be beneficial in manufacturing parts that are not requiring a high level of details, where we can sacrifice the aesthetic of the model due to its functionality. In terms of cost reduction, this finding represents a considerable improvement because, with the same tools and quantity of raw material, a product can be manufactured with less energy and using the same nozzle.

\section{REFERENCES}

Baich L., Marie H., Manogharan G.P., Study of Infill Print Design on Production CostTime of 3D Printed ABS Parts, Int. J. of Rapid Manuf., 5, Nos 3/4, 308-319, (2015).

Gibson I., Rosen D.W., Stucker B., Additive Manufacturing Technologies: 3D Printing, Rapid Prototyping, and Direct Digital Manufacturing, $2^{\text {nd }}$ Ed., Springer, New York, 147-173, 2015.

Hermann S, 2019, The Effect of Extrusion width on Strength and Quality of $3 d$ Prints, CNC Kitchen, viewed: February 02, 2020, $<$ https://www.cnckitchen.com/blog/the-effect-of-extrusion-width-on-strengthand-quality-of-3d-prints>.

Rajpurohit S.R., Dave H.K., Analysis of Tensile Strength of a Fused Filament Fabricated PLA Part Using an Open-Source 3D Printer, The Int. J. of Adv. Manuf. Tech., 101, 1525-1536 (2019).

Redwood B., Schöffer F., Garret B., The 3D Printing Handbook: Technologies, Design and Applications, $1^{\text {st }}$ Ed., 3D Hubs B.V., Amsterdam, 34-70, 2017.

Soares B. J., Finamor J., Silva F.P., Roldo L. Candido L.H., Analysis of the Influence of Polylactic Acid (PLA) Colour on FDM 3D Printing Temperature and Part Finishing, Rapid Prototyping J., 24, No. 8, 1305-1316 (2018).

Weiner H., Fused Filament Fabrication - Simply Explained, ALL3DP, Viewed: February 05, 2020, https://all3dp.com/2/fused-filament-fabrication-fff-3dprinting-simply-explained/ (2020).

Zuza M., Everything About Nozzles with a Different Diameter, PrusaPrinters, Viewed: February 09, 2020, https://blog.prusaprinters.org/everything-about-nozzleswith-a-different-diameter/ (2018). 


\section{IFLUENȚA PARAMETRILOR REDUCŢIEI ÎN IMPRIMAREA 3D ASUPRA TIMPULUI DE FABRICAȚIE}

\section{(Rezumat)}

În zilele noastre, Fabricația cu Filament Fuzibil este una dintre cele mai răspândite tehnologii de Fabricație Aditivă printre utilizatorii de rând, datorită costului scăzut al echipamentelor și al varietății mari de materiale disponibile pe piață. Chiar dacă este folosită de o varietate mare de utilizatori, nu toți folosesc parametrizarea avansată a proceselor, preferând setările implicite cu mici intervenții asupra parametrilor de bază precum înălțimea stratului de depunere, număr de perimetre și grad de umplere. În ceea ce privește diametrul reducției, câteva avantaje și dezavantaje implică utilizarea acestora în relația timp de fabricație - calitatea suprafeței. Utilizarea reducțiilor de dimensiuni mai mari prezintă avantaje precum reducerea timpului de execuție, risc minim de înfundare a reducției și altele. Acestea duc la pierderea rezoluției pentru detaliile de mici dimensiuni și structuri suport mult mai greu de îndepărtat. Prin ajustarea parametrilor reducției precum lățime și temperatură de extrudare a fost posibilă obținerea de rezultate similare prin intermediul unei reducții cu diametru standard. Obiectivul principal al acestui studiu a fost verificarea necesității utilizării reducțiilor cu diametru mai mare pentru reducerea timpului de fabricație, sau rezultate comparabile pot fi obținute prin utilizarea unor reducții cu diametru mai mic. În final am reușit reducerea timpului de execuție la jumătate comparativ cu timpul de depunere inițial. 